The 1994 Roscoe Pound Lecture

Professor Harold Hongju Koh*

\title{
Transnational Legal Process
}

\section{TABLE OF CONTENTS}

I. Introduction ................................ 181

II. What is Transnational Legal Process? ................ 183

III. The Evolution of Transnational Legal Process .......... 186

A. The Evolution of Legal Process Scholarship ........ 186

B. The Evolution of International Scholarship ........ 191

IV. Why Nations Obey ........................... 194

A. When Nations Have Obeyed .................. 194

B. Explaining Why Nations Obey ................ 199

1. Interest.............................. 199

2. Identity............................. 201

3. Interaction and Internalization............. 203

V. Conclusion $. . . \ldots \ldots \ldots \ldots \ldots \ldots \ldots \ldots \ldots \ldots \ldots \ldots, 206$

\section{INTRODUCTION}

It is with a sense of homecoming that I deliver this lecture bearing the name of Dean Roscoe Pound, a legendary figure in my own home. My late father, Dr. Kwang Lim Koh, an international law professor from Korea, came to Harvard Law School in the early 1950s to pursue his graduate education. Each morning at 5:00 a.m., he would rise and walk through the dark streets of Cambridge to his carrel deep in the

Copyright held by Harold Hongju Koh and the Nebraska LAw Revrew.

* Gerard C. and Bernice Latrobe Smith Professor of International Law and Director, Orville H. Schell, Jr., Center for International Human Rights, Yale University. The following is a lightly edited and footnoted version of the 1994 Roscoe Pound Lecture, delivered on October 28, 1994 at the University of Nebraska College of Law. An earlier version was presented as the inaugural lecture for the Gerard C. and Bernice Latrobe Smith Professorship of International Law at Yale Law School. This essay sketches the argument underlying a forthcoming book, tentatively entitled Why Nations Obey: A Theory of Compliance With International Law. It should be disclosed that the author participated in several of the cases discussed here as an attorney. See United States v. Alvarez-Machain, 504 U.S. 655 (1992)(counsel for amicus curiae); Sale v. Haitian Centers Council, 509 U.S. 155 (1993) and 823 F. Supp. 1028 (E.D.N.Y. 1993)(Counsel of Record for Haitian refugees); Cuban-American Bar Ass'n v. Christopher, 43 F.3d 1413 (11th Cir. 1995)(Of Counsel to Cuban plaintiffs). 
bowels of Langdell Hall, where invariably, he would find just one other person stirring: Harvard's eighty year-old former Dean, Roscoe Pound, wearing his visor and working on his five-volume treatise on jurisprudence.

Not until many years later, when I was myself studying at Harvard Law School, did I learn about Roscoe Pound as a legal scholar. Late one night, while reading about the revolt against formalism led by the father of sociological jurisprudence, 1 I wandered through Harvard's Law Library in search of Dean Pound's assembled works. I was startled to find an entire bookshelf in the Langdell stacks devoted to Pound's writings on domestic legal theory, but only three short pamphlets on international legal theory. 2

The image of a crowded bookshelf of domestic legal theory alongside near-empty shelves on international legal theory has haunted me ever since. Throughout my career, I have sought to understand this puzzling void in international legal scholarship. To many domestic legal scholars, the reason seems self-evident: they consider the very term "International Legal Scholarship" to be a complex oxymoron, like the "Holy Roman Empire" or the "New York Giants."3 Most domestic legal scholars tend to view international legal scholarship the same way. "If it's international," they say, "there can be no law involved. If it's international law, there can be no scholarship involved." They believe that when it comes to international legal scholarship-like Gertrude Stein's Oakland-there is "no there, there." To the extent that international law professors write articles, domestic scholars consider them at worst, irrelevant, and at best, thick description. In their view, international legal scholars have few ideas, and those they have do not really matter.

In this lecture, I argue that this notion is wrong. There is such a thing as international legal scholarship. Committing it and being committed to it are worthwhile activities. International legal scholars

1. See generally Davm Wigdor, Roscoe Pound (1974); Paul L. SaYre, The Life of ROSCOE POUND (1948).

2. One, a lecture Roscoe Pound gave in Leiden in 1922, was entitled The Philosophical Theories on International Law; the second was an address Pound gave at the Congress of International Law held at Harvard in 1926; and the third, Roscoe Pound, Philosophical Theory and International Law, 1 BibliotheCA VISSERIANA 73 (1932), is quoted in note 31 , infra.

3. A complex oxymoron-like the Holy Roman Empire (which was neither Holy, Roman, nor an Empire) or the New York Giants (which are neither New, from New York, or Giants) - may be distinguished from the more familiar simple oxymoron, such as "jumbo shrimp" or "working vacation." Other complex oxymorons of which I have been reliably informed include the Uniform Code of Military Justice, the Chicago School of Law, and the Union of Soviet Socialist Republics. 
do have an idea that has power, and that idea is Transnational Legal Process. 4

Transnational legal process provides the key, in my view, to understanding the critical issue of compliance with international law. Some years ago, in an oft-quoted phrase from his book How Nations Behave, Professor Louis Henkin asserted that "almost all nations observe almost all principles of international law and almost all of their obligations almost all of the time."5 But Henkin's hedged description of how nations behave leaves a critical question unanswered: namely, why do nation-states and other transnational actors obey international law, and why do they sometimes disobey it? That question-why nations obey-centrally challenges scholars of both international law and international relations. It vexes all the subjects that I teach, from international business transactions to international trade, from international organizations and the law of United States foreign policy to international human rights. For the last few years, it has also taxed my students in Yale Law School's Allard K. Lowenstein International Human Rights Clinic, as we have engaged in "transnational public law litigation" against a variety of foreign and United States government officials on behalf of victims of human rights abuses. 6

These claims raise three obvious questions. First, what is transnational legal process? Second, where did it come from? Third, how does it help explain why nations obey? In addressing these questions, I will argue that transnational legal process has been the dominant mode of international legal scholarship for the last few decades. I make the bolder claim that it not only lies at the heart of what international legal scholarship is about, but also at the heart of what international law scholarship should be about in the years ahead.

\section{WHAT IS TRANSNATIONAL LEGAL PROCESS?}

What, to begin with, is transnational legal process? Transnational legal process describes the theory and practice of how public and private actors - nation-states, international organizations, multinational enterprises, non-governmental organizations, and private individuals-interact in a variety of public and private, domestic and interna-

4. I have previously sketched some of these ideas in Harold Hongiu Koh, The "Haiti Paradigm" in United States Human Rights Policy, 103 Y ALE L.J. 2391, 2405-09 (1994); Harold Hongju Koh, Refugees, the Courts and the New World Order, 1994 UTAF L. Rev. 999; and Harold Hongju Koh, Transnational Public Law Litigation, 100 YALE L.J. 2347, 2398-2402 (1991)(discussing "The New International Legal Process").

5. Louis Henkin, How Nations Behave 47 (2d ed. 1979). See also Abram Chayes \& Antonia Chayes, On Compliance, 47 INT'z ORG. 175, 195 n.64 (1993).

6. See generally Koh, Haiti Paradigm, supra note 4, at 2391 (1994); Koh, Transnational Public Law Litigation, supra note 4, at 2347 (describing the litigation strategy underlying these cases). 
tional fora to make, interpret, enforce, and ultimately, internalize rules of transnational law.

Transnational legal process has four distinctive features. First, it is nontraditional: it breaks down two traditional dichotomies that have historically dominated the study of international law: between domestic and international, public and private. Second, it is nonstatist: the actors in this process are not just, or even primarily, nation-states, but include nonstate actors as well. Third, transnational legal process is dynamic, not static. Transnational law transforms, mutates, and percolates up and down, from the public to the private, from the domestic to the international level and back down again. Fourth and finally, it is normative. From this process of interaction, new rules of law emerge, which are interpreted, internalized, and enforced, thus beginning the process all over again. Thus, the concept embraces not just the descriptive workings of a process, but the normativity of that process. It focuses not simply upon how international interaction among transnational actors shapes law, but also on how law shapes and guides future interactions: in short, how law influences why nations obey.

To see these four features, consider the case of a California engineering firm called Dames \& Moore.7 In the late 1960s, the firm signed a contract to conduct a nuclear power plant site study. By most measures such a contract would constitute the classic "private domestic business deal," except that it was struck not with Pacific Gas and Electric, but with the Atomic Energy Organization of Iran. Moreover, this agreement was negotiated against a "public" backdrop not just of Iranian and United States domestic law, but of numerous bilateral and multilateral treaty commitments between the Iranian and United States governments. In 1979, a cataclysmic public event-the ouster of the Shah, his flight to the United States, and the seizure of 52 American hostages - triggered a surge of emergency host and homecountry regulations that dramatically affected these preexisting "private" deals. 8 The Atomic Energy Organization cancelled the contract, leading Dames \& Moore to sue Iran and its instrumentalities in United States district court. When the court vacated Dames \& Moore's judicial attachment of Iranian bank property based on the January 1981 executive orders implementing the United States-Iran executive agreement that freed the hostages, Dames \& Moore filed a

7. See Dames \& Moore v. Regan, 453 U.S. 654 (1981).

8. These regulations took the form of Iranian expropriatory actions and retaliatory United States government sanctions, including a trade embargo, an extraterritorial assets freeze, and, ultimately, an executive agreement that nullified judicial attachments on frozen Iranian assets, suspended private claims against Iran, and transferred them to arbitration before the newly created Iran-United States Claims Tribunal. 
new district court complaint against the United States, seeking to enjoin enforcement of those executive orders. That suit ultimately resulted in a historic loss in the United States Supreme Court a few months later. As a last resort, Dames \& Moore proceeded to the IranUnited States Claims Tribunal, which excluded it from the Tribunal's jurisdiction, citing to an Iranian forum-selection clause in its original contract. 9

The Iranian Hostages crisis illustrates each of the features of transnational legal process mentioned above. First, it does not fit traditional categories. It cannot be neatly cabined within "domestic law" - traditionally thought to govern conduct within borders-or "international" law, which has been thought to govern conduct across borders. Nor can it be characterized as "public" international lawthe law among nation-states, which encompasses what nations do to or with each other ${ }^{10}$-or "private" international law, classically thought of as cross-border law among nonstate actors. Second, the process was dynamic, not static. An ostensibly "private business deal" entered between a United States multinational and a developingcountry government dissolved into a domestic legal dispute, then percolated upward into a public international dispute, which was ultimately resolved by sovereign governments by an agreement based on public international and domestic public law in a manner that triggered both domestic constitutional claims by a multinational corporation against its own government in its own domestic courts and international expropriation and breach of contract claims against a foreign government in a newly-minted international forum. ${ }^{11}$

Third, the key actors in this process were not just nation-states, but also the International Monetary Fund, various multinational enterprises (particularly the large banks who participated in freezing and transferring the assets), and the individual hostages whose human rights were at stake. Fourth and finally, the interaction

9. See Dames \& Moore v. Iran, Award No. 97-54-3, Dec. 20, 1983, Iranian Assets Lit. Rep. 7,727 (Jan. 13, 1984); Dissenting Opinion of Judge Mosk, Dec. 21, 1983, Iranian Assets Lit. Rep. at 7,738 (Jan. 13, 1984).

10. E.g., making war and peace; forming international agreements; allocating rights to air, sea, and space; state responsibility; international organizations; and such topics as jurisdiction, immunities, and diplomatic relations.

11. For a similar process of mutation, witness transnational contract law, which began as customary international law-the law merchant or lex mercatoria-but transformed into English common law when England became the world's leading commercial power. Upon the founding of the United States, that English common law migrated to the United States as federal general common law. See Swift v. Tyson, 41 U.S. (16 Pet.) 1 (1842). Such contract law then became the subject of state codification in the Uniform Commercial Code until, in 1988, the United States became a party to the U.N. Convention for Contracts for the International Sale of Goods, an act that re-elevated transnational contract questions to positive international treaty law. 
among these transnational players was what Robert Cover calls "jurisgenerative."12 It not only generated law-the domestic private law of letters of credit, the domestic public law of executive power, the international private law of dispute-resolution, and the public international law of diplomatic relations law-but generated new interpretations of those rules and internalized them into domestic law that now guides and channels those actors' future conduct.

\section{THE EVOLUTION OF TRANSNATIONAL LEGAL PROCESS}

\section{A. The Evolution of Legal Process Scholarship}

If this is what transnational legal process is, where did it come from? Of course, the concept of transnational law is decades old; the phrase was coined by Phillip Jessup in his Storrs Lectures at Yale in 1956. Similarly, the concept of International Legal Process-studying law's role in the process of policy decisions in the international realms-was pioneered in a casebook developed by Abram Chayes, Tom Ehrlich, and Andreas Lowenfeld in 1968. Process inquiries also run through the work of Myres McDougal, Harold Lasswell, and Michael Reisman at Yale Law School on the world constitutive process of authoritative decision. ${ }^{13}$ Finally, the idea of Transnational Legal Problems-a category that mixes public and private, domestic and international, and embraces international human rights, international business transactions, and the law of U.S. foreign policy-was first captured by Harvard professors Henry Steiner and Detlev Vagts in a casebook that in turn grew out of a 1960 casebook on the Law of International Transactions and Relations authored by Milton Katz and then-Professor Kingman Brewster. 14

It is precisely because this idea is not new, that it has been overlooked. Precisely because it has been latent and inchoate, it has not been recognized, accepted, or specifically developed as a way of understanding and affecting the world. To make this case, let me take you briskly through two types of intellectual history: the history of scholarly discourse within international law in this century and the history of scholarly discourse between international law and its companion discipline of international relations.

12. Robert M. Cover, The Supreme Court, 1982 Term-Foreword, Nomos and Narrative, 97 HaRv. L. REv. 4 (1983).

13. See, e.g., Harold D. Lasswell \& Myres S. McDougal, Jurisprudence for a Free Society: Studies In Law Science and Policy (1992); Myres S. McDougal \& W. Mrchael Reisman, International Law In Comparative Perspective (1981); W. Mrchael Reisman \& ANDrew WILlaAd, International Incidents (1988).

14. H. Steiner et al., Transnational Legat Problems (4th ed. 1994); Milton Katz \& KINGMAN BREWSTER, InTERnational Transactions and Relations: Cases aND Materials (1960). 
Within the American legal academy, we are all familiar with the evolution of domestic legal scholarship from Christopher Columbus Langdell to Catherine MacKinnon. In this century alone, we have moved through a series of well-charted intellectual eras. This history began with Langdell's Legal Formalism - the case method and the notion of law as a science-followed by the attack on Formalism by the Legal Realists of the twenties and thirties. ${ }^{15}$ Realism itself triggered two principal responses, designed to curb its perceived indeterminacy: the codification movement, represented by the American Law Institute's Restatements, the Uniform Commercial Code, and what Guido Calabresi has called the "age of statutorification;"16and the Legal Process movement of Hart and Sacks 17 and Hart and Wechsler 18, which focused on the study of legal institutions, "reasoned elaboration," neutral principles, and the optimism - fed by Robert Dahl's school of political science-that rational but orderly policy change could be achieved through a pluralistic political process.

In the 1960s, we saw a three-part response to the Legal Process movement: first, the rights movement-the due process 19 and equal protection revolutions 20 led by the work of the Warren Court; second, poverty law, heralded by the rise of clinical studies, poverty and entitlements law, and Charles Reich's The New Property;21 and third, the Law And Movement, which brought to American law faculties economists, sociologists, anthropologists, psychiatrists, doctors, and others. In the 1970s, when I went to law school, each of these strands continued and broadened. Legal process continued in the work of constitutional scholars like John Hart Ely and Jesse Choper. The rights movement-carried forward on the academic front by Laurence Tribe ${ }^{22}$ and Ronald Dworkin ${ }^{23}$ and on the activist side by such groups as the NAACP Legal Defense Fund, Planned Parenthood, NOW, and the ACLU-shifted focus from the activist trends of the Warren Court

15. Ironically, Roscoe Pound's own work on sociological jurisprudence, which attacked this "mechanical jurisprudence," helped give birth to the very school with which he ultimately went to war: the legal realists, like Karl Llewelyn, William O. Douglas, Thurman Arnold, Jerome Frank, Leon Green, and Underhill Moore, many of whom found their home, not at Pound's Harvard, but at Yale and Columbia Law Schools.

16. Gumo Calabrest, a Common Law for the Age of Statutes (1982).

17. Henry M. Hart \& Albert M. Sacks, The Legal Process (1995).

18. Henry M. Hart \& Herbert Wechsler, The Federal Courts and the Federal SYstem (1953); Herbert Wechsler, Toward Neutral Principles in Constitutional Law, 73 Harv. L. Rev. 1 (1959).

19. On the criminal side, see, e.g., Miranda v. Arizona, 384 U.S. 436 (1966), and the civil side, see, e.g., Goldberg v. Kelly, 397 U.S. 254 (1970).

20. See, e.g., Brown v. Board of Educ., 347 U.S. 483 (1954).

21. Charles A. Reich, The New Property, 73 Yale L.J. 733 (1964).

22. Laurence H. Tribe, american Constitutional Law (1978).

23. RONALD DwORKIN, TAKING Rights SERIOUSLy (1977). 
to the counter-revolutionary tendencies of the Burger Court.24 Poverty law and clinical education continued to fight for status within American law schools. The Law And movement, now dominated by Law and Economics, bifurcated into a hard, conservative strand based at Chicago and led by now-Judge Richard Posner25 and a somewhat more liberal camp centered at Yale, 26 with the Law And Society movement maintaining footholds in Wisconsin and elsewhere.27

The 80's and 90's have witnessed what George Priest has called the "new scientism" in legal scholarship: the continuing strength of the Law and Economics movement, the emergence of rational choice and organizational theory, 28 and new critical schools of thought and methodology-critical feminist, race, and legal studies, law and literature, and postmodernism. Yet through these years, a group of progressive legal scholars kept the Legal Process movement alive by informing it with a rights tradition.29 They saw the law's legitimacy as resting not just on process but also on its normative content. They viewed lawmaking as not merely the rubberstamping of a pluralistic political process, but as a process of value-creation in which courts, agencies, and the people engage in a process of democratic dialogue. In the last few years, these thinkers have spawned a third generation of public law scholars-calling themselves the "new public law movement"30-who

24. See, e.g., V. Blasi, The Burger Court: The Counter-revolution That Wasn't (1979).

25. See, e.g., Richard A. Posner, Economic Analysis of Law (1st ed. 1973).

26. See, e.g., Gumo Calabresi, The Costs of Accidents: A legal and Economic ANALYSIS (1970).

27. See, e.g., the extensive writings in the Law \& Society Review, now more than thirty years old; David Trubek, Back to the Future: The Short, Happy Life of the Law and Society Movement, 18 FLA. Sr. U. L. REv. 1 (1990).

28. See, for example, The Journal of Law, Economics, \& Organization, now more than eleven years old.

29. See, e.g., Bruce Ackerman, We the People: Foundations (1991)(work on constitutional moments); Robert Burt, The Constitution In Conflict (1992); CalaBResi, supra note 16; Robert Cover et al., Procedure (1989); John Hart Ely, Democracy and Distrust: A Theory OF Judiclal Review (1980); JerRy Mashaw, Due Process IN THE ADMrnistrative State (1985); Abram Chayes, The Role of the Judge in Public Law Litigation, 89 HaRv. L. Rev. 1281 (1976); Robert Cover \& T. Alexander Aleinikoff, Dialectical Federalism: Habeas Corpus and the Courts, 86 YALE L.J. 1035 (1977); Owen Fiss, The Supreme Court, 1978 Term-Foreword: The Forms of Justice, 93 Harv. L. Rev. 1 (1979)(work on procedure). Some of Laurence Tribe's work on American Constitutional Law also partakes of this tradition. See, e.g., Laurence Tribe, Structural Due Process, 10 HARv. C.R.-C.L. L. REv. 269 (1975)(positing active role for courts in policing structures through which policies are formed and applied).

30. See generally William N. Eskridge, Jr. \& Phillip P. Frickey, Introduction to Henry M. HaRT, JR. \& Albert M. SACKS, The Legal Process cxxv-cxxxiv (1994) (reviewing recent literature); William N. Eskridge, Jr. \& Phillip P. Frickey, The Supreme Court, 1993 Term, Foreword: Law As Equilibrium, 108 HaRv. L. REv. 1 (1994); William N. Eskridge, Jr. \& Gary Peller, The New Public Law Movement: Moderation as a Postmodern Cultural Form, 89 MrCH. L. REv. 707 (1990). For 
have tried to couple the normativity of process with interdisciplinary understandings of how law is made in writings about legislation, statutory interpretation, civic republicanism, and the like.

From the perspective of international law, what is most striking about this recitation of intellectual history is the blind assumption that during these eras, international law scholarship has just been sitting there, caught in a time warp of obscure Latin terminology: pacta sunt servanda, rebus sic stantibus, jus ad bello, jus in bello. In fact, international legal scholarship has moved through precisely the same stages of intellectual development as domestic legal scholarship, from rule formalism to new scientism. Again, the story begins with the transition from Formalism - typified by the classical study of international law as a science at the Hague Academy of International Law-to Legal Realism, captured in the policy science work of Myres McDougal and Harold Lasswell. ${ }^{31}$ As in the domestic realm, two principal responses to Legal Realism emerged: the codification movement, represented by the Harvard Research on International Law, the International Law Commission's drafting activities, the American Law Institute's Restatements of Foreign Relations Law, and the international legal process work of Abram Chayes, Thomas Ehrlich, and Andreas Lowenfeld (which like Hart and Sacks, posited that legal issues mainly arise not before courts, but in the process of making policy decisions, with lawyers playing a more important role than judges, and consent playing a greater role than command). 32

The 60's and 70's witnessed the same reactions to Legal Process: the rise of the international human rights movement in the work of Louis Henkin, Myres McDougal, Louis Sohn, and Tom Buergenthal;

other examples, see WILLIAM N. EsKRmge, JR., DyNAMIC STATUTORY INTERPRETATTON (1994); Philip P. Frickey, Congressional Intent, Practical Reasoning, and the Dynamic Nature of Federal Indian Law, 78 Cal L. Rev. 1137 (1990); T. Alexander Aleinikoff, Updating Statutory Interpretation, 87 Mrch. L. REv. 20 (1988); Daniel Farber, Statutory Interpretation and Legislative Supremacy, 78 GEo. L.J. 281 (1989); Cass Sunstein, Interpreting Statues in the Regulatory State, 103 HARV. L. Rev. 405 (1989).

31. See, e.g., LASSWELl \& McDougal, supra note 13; Myres S. McDougat, InTERnatinal LaW, Power, and Policy: A Contemporary Conception (1954); McDouGAL \& REISMAN, supra note 13; REISMAN \& WIILARD, supra note 13. In important ways, McDougal and Lasswell's view of law as a social, not a natural science, picked up on notions of sociological jurisprudence first developed by Dean Roscoe Pound. See, e.g., McDougal, supra at 137 (quoting Roscoe Pound, Philosophical Theory and International Law, 1 BIBLIOTHECA VisserianA 73, 89 (1932)(demanding "a functional critique of international law in terms of social ends, not an analytical critique in terms of itself, and above all that shall conceive of the legal order as a process and not as a condition.")). In other work, I am exploring the role of Myres McDougal's Legal Realism as the critical link between the domestic and international worlds of legal scholarship.

32. Abram Chayes et al., International legal Process: Materials for an IntroDUCTORY COURSE (1968). 
international poverty law, as focused on the subject of law and development; 33 and a truncated version of the Law And movement, with Law and Economics, for example, making some headway in studies of the GATT 34 and Law and Society in the study of customary international norms.

Not surprisingly, in the 1980s and 90's a new scientism came to international legal scholarship as well, with the arrival of high-tech economics in international trade law, 35 the introduction of rational choice theory to the study of arms control and trade, 36 and a number of critical schools coming to grips with contemporary issues. Thus, critical feminist theory now confronts notions of sovereignty and violence against women in Bosnia, ${ }^{37}$ postmodernism tackles problems of ethnic nationalism, 38 and critical race theory examines the rights of indigenous minorities. ${ }^{39}$ Law and economics, critical legal studies,40 postmodernism and feminism have each developed theoretical analogues and counterparts in international legal scholarship. But these new theoretical schools of international legal scholarship, which grew largely out of a resurgence of theory in domestic American legal scholarship, have been the doughnut and not the hole, the periphery and

33. See, e.g., David M. Trubek \& Marc Galanter, The Scholars in Self-Estrangement: Some Reflections on the Crisis in Law and Development Studies in the United States, 4 Wisc. L. REv. 1062 (1974); David M. Trubek, Toward a Social Theory of Law: An Essay on the Study of Law and Development, 82 YaLE L.J. 1 (1972).

34. See, e.g., KenNeth W. DAM, The GATT-LAW AND INTERnational Economic ORGANIZATION 214-21, 274-95 (1970); Warren F. Schwartz \& Eugene W. Harper, Jr., The Regulation of Subsidies Affecting International Trade, 70 MrCH. L. REv. 831 (1972).

35. See, e.g., Alan O. Sykes, Countervailing Duty Law: An Economic Perspective, 89 CoLum. L. Rev. 199 (1989).

36. For recent scholarship espousing this "rationalistic" view of international law in trade and arms control law, see, for example, Kenneth W. Abbott, The Trading Nation's Dilemma: The Functions of the Law of International Trade, 26 Harv. INT'L L.J. 501 (1985); Kenneth W. Abbott, 'Trust But Verify': The Production of Information in Arms Control Treaties and Other International Agreements, 26 CORNELL INT'L L.J. 1 (1993).

37. See, e.g., Catharine MacKinnon, Crimes of War, Crimes of Peace: On Human RigHrs 83 (Stephen Shute \& Susan Hurley eds., 1993); Hilary Charlesworth et al., Feminist Approaches to International Law, 85 AM. J. INT't L. 613 (1991); Hilary Charlesworth \& Christine Chinkin, The Gender of Jus Cogens, 15 HumaN RTS. Q. 63 (1993); Karen Engle, International Human Rights and Feminism: When Discourses Meet, 13 Mich. J. INT'L L. 517 (1992).

38. See, e.g., Nathaniel Berman, "But the Alternative is Despair": Nationalism and the Modernist Renewal of International Law, 106 HARv. L. Rev. 1792 (1993).

39. Cf. Chris Tennant, Indigenous Peoples, International Institutions, and the International Legal Literature from 1945-1993, 16 Human RIGHTS Q. 1 (1994).

40. See, e.g., Marti Koskenniemi, From Apology to Utopia: The Structure of InTERnational Legal Argument (1989); David Kennedy, A New Stream of International Law Scholarship, 7 WIs. INT'L L.J. 1 (1988); Nigel Purvis, Critical Legal Studies in Public International Law, 32 HARv. INT'L L.J. 81 (1991). 
not the center. What the center has been, I will defer for the moment, but let me leave one hint: transnational legal process.

\section{B. The Evolution of International Scholarship}

So much for the scholarly discourse within international law. What about the discourse between international law and its sister disciplines, particularly International Relations theory? Here the picture was substantially clouded by the Cold War.

The years immediately following World War II represented the heyday of international law: the rise of the United Nations and international organizations, both political and economic, the international human rights movement, and the notion that international lawyers could be both the architects and executors of a new world order under law. In the main, those who designed the postwar international system were lawyers who believed in the rule of law, not power, in international affairs and in the willingness of states to cooperate within international institutional and constitutional frameworks.

But as the Cold War set in and reality intruded, the fields of international law and international relations became oddly estranged. Although the two disciplines covered much of the same territory, they evolved independently of one another, pursuing different analytic missions and reaching different conclusions about the function and influence of law. International lawyers and international relations theorists adopted an odd division of labor regarding the intellectual projects that they would pursue. International lawyers began to perform three kinds of tasks: first, description of the law through analysis of customary law and treaties; second, application of the law to particular cases, e.g., evaluating the lawfulness of particular instances of state conduct; and third, modest prescription about what the rule of law should be, particularly in certain growth areas, such as international human rights.

At the same time, international lawyers tended to avoid two other tasks: causal explanation and prediction. Thus, Louis Henkin's famous book carries the descriptive title How Nations Behave, attempting precious little causal or predictive analysis of why nations obey, what kinds of law will emerge in certain issue areas, and under what circumstances international law will or will not be obeyed. Yet, it was precisely these questions upon which international relations theorists-particularly in the area of political science-began to focus, in part because they thought of themselves as scientists, engaged in a value-free, nonprescriptive inquiry into causal explanation.

By the early 1980 s, the schism between the two disciplines was nearly complete. International lawyers tended to find the glass half full, typified by Henkin's famous phrase, "almost all nations observe almost all principles of international law and almost all of their obli- 
gations almost all of the time." 41 International relations theorists, by contrast, (particularly the realists) found such legalism naive and utopian, and tended toward the opposite conclusions: that international law always fails in the big case; that international law cannot be enforced; and that when power and law come into conflict in international affairs, politics is the phenomenon and law is the epiphenomenon. Law, they concluded, has no independent, driving force in international affairs. Law is simply a mask for power, and in the end power prevails. The irony, of course, is that much the same conclusion was reached in law not by the right wingers but by the leftwing critical legal studies scholars, and so in the international realm, the political realists and the critical legal theorists made strange bedfellows.

But notice that the realists regularly made four simplifying assumptions to support their findings: first, that international affairs are a state of anarchy; second, that states are the principal actors in international affairs; third, that states act rationally in deciding whether to engage in cooperation or conflict with other states in the system; and fourth, that the principal interest of rational states is in seeking and maintaining power and security.

Each of these four core assumptions is demonstrably false, particularly in the realm of international economic law. In the modern global economy, the idea that the principal interest of rational states is in seeking and maintaining power and security is falsified by the growing importance and interdependence of economic transactions. Superpowers such as Japan or the European Community have achieved economic prosperity in good part because of their success in externalizing security concerns to other nations. Similarly, the notion that states are the principal actors in international affairs cannot hold sway in a world where nonstate actors-e.g., banks, multinational enterprises, the Paris and London Clubs-dwarf the power of microstates (like Haiti and Burundi) in a system of international commercial transactions that operates largely without governmental intervention. Third, domestic political science learning about bureaucratic politics long ago undercut the fiction that states act rationally in deciding whether and how to engage other states in the global trading system. No one seriously believes that the omnibus trade bill that implemented the Uruguay Round, for example, was the product of a single, rational guiding intelligence. Fourth, as liberal neoinstitutionalists like Robert Keohane recognized years ago, the notion that international affairs are a state of anarchy must address the puzzling persistence of interstate cooperation, and growth of formal

41. HeNkIN, supra note 5 , at 47 . 
and informal, public and nonpublic, mechanisms to promote the evolution of norms to further that cooperation. 42

I have challenged each of these four notions in the realm of international economic law. But in other global issue areas, such as international human rights and environmental law, it is equally true that power and security are not the only concerns, that states are not the only important actors, that states do not behave rationally, and that international relations are not in a state of anarchy.43 The fact that burglaries still occur in Nebraska does not demonstrate a state of anarchy, nor does it prove that laws against burglary have no force and effect. Similarly, the World Trade Center and Oklahoma City bombings do not disprove the existence of international norms against terrorism, multilateral treaties against terrorism, or international regimes to battle terrorism. 44 Nor do defaults on sovereign debt or the persistence of environmental degradation disprove the vast web of global norms, principles, and decisionmaking procedures designed to

42. See, e.g., Robert O. KeOHANe, Jr., AFter Hegemony: CoOperation AND Discord IN THE WORLD POLITICAL ECONOMY (1984). In the 1970s this more optimistic, "rationalistic" picture of why nations cooperate began to center on what some call "liberal institutionalism": functionalism, regionalism, and interdependence theory. See Joseph Grieco, Cooperation Among Nations: Europe, America, AND NON-TARIFF BARRIERS TO TRADE 27 (1990). But the resurgence of international tensions and bipolar conflicts during the later years of that decade undermined these early efforts and appeared to reinforce core realist assumptions. In the $1980 \mathrm{~s}$, the demonstrable continuation of interstate cooperation fostered a new, highly influential strand of liberal institutionalism focused upon "regime theory." A regime, as defined by political scientist Stephen Krasner, is a set of "implicit or explicit principles, norms, rules, and decision-making procedures around which actors' expectations converge in a given area of international relations." STEPHEN KRASNER ED., INTERNATIONAL REGIMES 2 (1983). Although the precise boundaries of the regime concept remain indistinct, the core notion is that institutional, governmental, and private participants in a given issue area will develop a set of governing arrangements, along with a set of ideologies and expectations, that both restrain the participants and provide means for achieving their common aims. Thus, for example, regime theory notes that international debt questions are not settled entirely within the confines of an international organization like the International Monetary Fund, but rather, within the broader "debt regime," a set of arrangements in which intergovernmental organizations, national governments, private and public debtors and creditors, and informal arrangements like the London and Paris Clubs all participate. Regime theorists further recognize that the phenomenon ultimately to be studied is not the functioning of international organizations per se-e.g., the United Nations-but the broader phenomenon of international cooperation-e.g., the regime of "international peacekeeping"-as it transpires both within and without institutional settings.

43. When political scientists tell me, "international relations are in a state of anarchy," I usually answer, "T'm from Yale Law School. I know from anarchy, and this is not it."

44. See generally Harold Hongju Koh, Civil Remedies for Uncivil Wrongs: Combatting Terrorism through Transnational Public Law Litigation, 22 TEx. INT'L L.J. 169 (1987)(describing these regimes). 
guard against such transnational events. So, in the end, I find myself sounding like Louis Henkin, arguing that the glass is half full and that "almost all nations observe almost all principles of international law almost all of the time." Just because the $55 \mathrm{mph}$ speed limit is not strictly enforced does not mean that that law lacks all power. When the speed limit is 55 , people tend to drive 65 , not 85 . The law may be underenforced, it may be imperfectly enforced, but it is enforced, not by a simple domestic process of legislation, adjudication, and executive action, but by a process of complex enforcement that transpires in a variety of public and private fora, under a variety of domestic and international laws, triggered by a variety of governmental and nongovernmental actors. In short, international law is enforced by a transnational legal process, which is triggered not just by the United States and Russia, but also by the Security Council, the GATT, Exxon, Greenpeace, the Paris Club, Amnesty International, and the Lowenstein International Human Rights Clinic at Yale Law School.

\section{WHY NATIONS OBEY}

What about the claim that international law is epiphenomenal, and plays no driving role in international affairs? One can believe this claim only if you are not willing to look closely and carefully enough at the process by which law intersects with power in international affairs. Take three examples, from the areas of arms control, international criminal law, and international human rights.

\section{A. When Nations Have Obeyed}

Take first the story of the ABM Treaty Debate.45 In October 1985, the Reagan Administration proposed the Strategic Defense Initiative (SDI), popularly called "Star Wars," which amounted to an antiballistic missile system for American territorial defense. Unfortunately, in 1972, the United States and the USSR had signed a bilateral treatythe Anti-Ballistic Missile Treaty-that expressly banned the development of space-based systems for the territorial defense of our country.46 To skirt the plain language of the Treaty, the Reagan Administration proposed to "reinterpret" the ABM Treaty to permit Star Wars, i.e., to amend it without the consent of either the Senate or our treaty partner. That decision triggered an eight-year battle in which numerous present and former government officials, including six former Secretaries of Defense and numerous key Senators (princi-

45. This history is reviewed in Harold Hongju Koh, The Treaty Power, 43 U. Miam L. Rev. 106 (1988).

46. Abram Chayes \& Antonia Chayes, Testing and Development of "Exotic" Systems under the ABM Treaty: The Great Reinterpretation Caper, 99 HARv. L. REv. 1956 (1986). 
pally Sam Nunn), rallied in support of the original interpretation of the treaty. 47

The ABM controversy never reached any court, but raged in many forums: Senate hearings, debates over other arms control treaties, law review articles, and op-ed columns. In the end, Congress withheld appropriations from SDI tests that did not conform with the treaty; the Senate reported the ABM Treaty Interpretation Resolution, which reaffirmed its original understanding of the treaty; and in 1988, the Senate attached a condition to the Intermediate-Range Missile Treaty (INF treaty), which specified that the U.S. shall interpret the treaty in accordance with the understanding shared by the President and the Senate at the time of advice and consent. 48 In response, the Reagan and Bush Administrations still claimed that their broad reinterpretation was "legally correct," but announced that they would comply with the original understanding as a matter of "policy." In 1993, the episode ended, when President Clinton repudiated the unilateral Reagan reinterpretation and announced that his administration would abide by the original $A B M$ treaty interpretation.

None of this legal dispute reached any court. Indeed, had one stopped tracing the process of the dispute in 1987, one might have concluded that the United States had breached the treaty and gotten away with it. But in the end, the ABM Treaty Reinterpretation Debate is a story of how a powerful nation, the United States, returned to compliance with international law.

Much the same lesson applies to the saga of extraterritorial kidnapping played out in United States $v$. Alvarez-Machain.49 In that case, the Supreme Court held that a Mexican accused's forced abduction by U.S. agents from Mexican territory, without resort to an existing bilateral extradition treaty, did not divest U.S. courts of criminal jurisdiction to try that defendant.50 But the Supreme Court's decision did not end the story. Alvarez-Machain sparked intense media criticism and protests from political leaders in Mexico, Canada, Europe, and the Caribbean.51 The decision triggered congressional

47. A key role in the fight against the $A B M$ treaty reinterpretation was played by Gerard C. Smith, the chief American negotiator at SALT I and one of the principal negotiators of the ABM Treaty. Smith chaired the Board of an important nongovernmental organization, the Arms Control Association, and a grassroots organization, the National Committee to Save the ABM Treaty. He is the namesake of the professorship I now hold.

48. See Harold Hongu Koh, The National Security Constitution: Sharing Power AFter the Iran-Contra AfFair 43 (1990).

49. 504 U.S. 655 (1992).

50. In dissent, Justice Stevens argued that "most courts throughout the civilized world . . . will be deeply disturbed by the 'monstrous' decision the Court announces today." Id. at 687 (Stevens, J., dissenting)(citations omitted).

51. See Jonathan A. Bush, How Did We Get Here? Foreign Abduction After AlvarezMachain, 45 StAN. L. REv. 939, 941-42 \& nn.11-15 (1993). 
hearings, 52 proposals for remedial legislation, and an internal Justice Department review of the policy of transborder kidnapping.53 The Permanent Council of the Organization of American States requested a legal opinion regarding the international legality of the Supreme Court's decision from the Inter-American Juridical Committee, which concluded that "the decision is contrary to the rules of international law."54 Later that year, an exasperated district judge acquitted Alvarez-Machain of criminal charges,55 and Alvarez promptly filed a civil action in federal court against the U.S. officials who ordered his kidnapping.56 Finally, in June 1993, amid the North American Free Trade negotiations, Secretary of State Warren Christopher announced that the United States and Mexico had agreed to amend the U.S.-Mexico Extradition Treaty to prohibit transborder kidnappings. Thus, once again, the United States reluctantly obeyed.57

My final example is a case I know too well: the extraterritorial return of Haitian and Cuban refugees. Beginning in the spring of 1992, the Bush Administration began to intercept and directly return Haitians fleeing Haiti on the high seas, in apparent violation of past governmental precedents 58 and the "nonrefoulement" requirement of

52. See Kidnapping Suspects Abroad: Hearings Before the Subcomm. on Civil and Constitutional Rights of the House Comm. on the Judiciary, 102d Cong., 2d Sess. 82 (1992).

53. See Paul Hoffman, U.S. Must Not Kidnap Suspects Abroad, NewsDaY, Dec. 2, 1993, at 114 (noting legislation introduced by Senator Moynihan and internal Justice Department review ordered by Attorney General Reno in response to decision).

54. Organization of American States, Permanent Council, Legal Opinion on the Decision of the Supreme Court of the United States, 4 CRIM. L. F. 119, 124 (1993). The United Nations Working Group on Arbitrary Detention further determined that Alvarez had been arbitrarily detained in violation of international law.

55. Seth Mydans, Judge Clears Mexican in Agent's Killing, N.Y. Trmes, Dec. 15, 1992, at $\mathrm{A} 20$.

56. Alvarez-Machain v. United States, No. CV 93-4072 JGD (JHx)(C.D. Cal. 1994).

57. U.S. Curbs Its Agents in Mexico, New HAVEN REg. (June 22, 1993), at 20.

58. Various contemporaneous government documents and instruments implementing the interdiction program confirmed that the nonrefoulement obligation applied even on the high seas. President Reagan's first Executive Order on interdicting Haitians stated that in order to ensure "the strict observance of our international obligations concerning those who genuinely flee persecution in their homeland," "that no person who is a refugee will be returned without his consent." Executive Order No. 12,324, 46 Fed. Reg. 48109, 48109 (1981). INS Guidelines issued to implement the 1981 Executive Order further mandated that INS personnel be constantly watchful "for any indication (including bare claims) that a person or persons on board the interdicted vessel may qualify as refugees under the United Nations Convention and Protocol." INS Role In and Guidelines For Interdiction at Sea, October 6, 1981 (emphasis added), quoted in Brief for Respondents at 31, Sale v. Haitian Centers Council, 509 U.S. 155 (1993). Finally, two opinions from the Justice Department's Office of Legal Counsel reaffirmed the point. See Proposed Interdiction of Haitian Flag Vessels, $5 \mathrm{Op}$. Off. Legal Counsel 242, 248 (1981)(reasoning that interdicted Haitians "who claim that they 
Article 33 of the 1951 U.N. Refugee Convention Relating to the Status of Refugees.59 An ad hoc coalition of human rights lawyers, including Yale's Lowenstein International Human Rights Clinic, challenged that policy unsuccessfully at the Supreme Court against the Clinton Administration, which surprised everyone by maintaining the Bush direct return policy upon taking office.60 Thus, as of June 1993, it appeared that two American presidents had violated a core international human rights norm with impunity.

But once again, the Supreme Court's decision was not the last word on the legality of the interdiction policy under international, as opposed to domestic, law. The U.N. High Commissioner on Refugees, whose support the Clinton Administration required elsewhere in the world, loudly protested the Supreme Court's ruling.61 Other human rights groups began pressing arguments similar to those urged by the $H C C$ plaintiffs as a basis for challenging the U.S. government's policy before the Inter-American Commission on Human Rights. 62

will be persecuted ... must be given an opportunity to substantiate their claims."); Memorandum from Larry L. Simms, Deputy Assistant Att'y Gen., Off. of Legal Counsel, to the Assoc. Att'y Gen. (Aug. 5, 1981)( "Those who claim to be refugees must be given a chance to substantiate their claims [under Article 33]."), quoted in Joint Appendix at 222, Sale v. Haitian Centers Council, 509 U.S. 155 (1993).

59. 19 U.S.T. 6259, 189 U.N.T.S. 150, done July 28, 1951 ("[n]o Contracting State shall expel or return ("refouler") a refugee in any manner whatsoever to the frontiers of territories where his life or freedom would be threatened on account of his ... political opinion.") (emphasis added). The United States became a party to the Refugee Convention when it acceded to the United Nations Protocol Relating to the Status of Refugees, Jan. 31, 1967, 19 U.S.T. 6223, T.I.A.S. 6577. For an account of this history, see Koh, The Haiti Paradigm, supra note 4.

60. See Sale v. Haitian Centers Council, 509 U.S. 155 (1993). Justice Stevens' opinion for the Court held that the nonrefoulement obligations of neither INA \& 243(h) nor Article 33 of the Refugee Convention applied to Haitians apprehended on the high seas, thereby articulating a domestic rule of "territorial nonrefoulement." Another wing of the litigation, however, won the release of more than 300 Haitians being held on Guantanamo, who had established prima facie claims of political asylum. Haitian Centers Council v. Sale, 823 F. Supp. 1028 (E.D.N.Y. 1993).

61. See U.N. High Commissioner for Refugees Responds to U.S. Supreme Court Decision in Sale v. Haitian Centers Council, 32 I.L.M. 1215 (1993)("[T]he obligation not to return refugees to persecution arises irrespective of whether governments are acting within or outside their borders. ... UNHCR considers the Court's decision a setback to modern international refugee law. . . .").

62. The Inter-American Commission on Human Rights considered a petition brought by the Center for Human Rights and Constitutional Law which challenged the Haitian interdiction program as a violation of the American Declaration of the Rights and Duties of Man and the American Convention on Human Rights, OAS Treaty No. 36. In March 1993, the Commission issued an interim Resolution adopting Provisional Measures, "[c]alling upon the United States Government to review as a matter of urgency its practice of stopping on the seas vessels destined for the USA with Haitians and returning them to Haiti without affording them an opportunity to establish whether they qualify as refugees," and noting that the U.S. policy prevents the exercise by the Haitians of the right to seek refuge. See 
As the Clinton Administration maintained its policy of direct return, domestic political pressure began to build. The African-American community began drawing attention to the gross inconsistency of the Haitian policy with our international obligations and the discriminatory treatment of Haitians vis-à-vis Cubans and other immigrant groups. TransAfrica leader Randall Robinson undertook a hunger strike to publicize the Haitians' plight, personalizing the issue and becoming a focal point for media attention. The African-American community magnified its voice through the forty-member Congressional Black Caucus (CBC), which in March 1994 sent President Clinton a letter announcing that "The United States' Haiti policy must be scrapped."63

- In May 1994, President Clinton finally conceded that his Haitian policy had failed. He abandoned his direct return policy, and shifted to a new policy of "safe haven" for Haitian refugees, pending Aristide's return. ${ }^{64}$ In the summer of 1994, tens of thousands of Cuban refugees began fleeing again on the high seas and were detained in Guantanamo camps, and after extensive new litigation, were ultimately released into the United States.65 Although the new "safe haven" policy itself proved fraught with problems under international human rights law, 66 amid the post-mortems on the Haitian crisis a salient fact got lost: that after several years of counterproductive noncompliance with the global norm against extraterritorial refoulement of refugees, at least for a time, the United States came back into compliance with that norm.

Case No. 10.675, discussed in Petitioners Release Resolution of the Inter-American Commission on Human Rights concerning U.S. Program of Haitian Refugee Interdiction, 32 I.L.M. 1215 (1993). In the spring of 1995, the Commission issued an interim order against the United States.

63. Peter J. Boyer, The Rise of Kweisi Mfume, NEw Yorken, Aug. 1, 1994, at 34.

64. Id. at 34. Other personnel changes, for example, the appointment of Strobe Talbott as Deputy Secretary of State, also apparently played a role in promoting reconsideration of the direct return policy. Initially, Clinton announced that he would shift to a new policy of subjecting fleeing Haitian boat people to full-fledged refugee interviews aboard United States Navy ships docked in the harbor at Kingston, Jamaica. But the policy change, coupled with favorable weather and new desperation in Haiti, coincided with a refugee outflow of more than 15,000 refugees that quickly swamped the capacity of the Jamaican processing facility. Thus, in July 1994, the Administration switched course again and announced that henceforth, all fleeing refugees would be given "safe haven" in various offshore camps, most prominently in Panama, Honduras, and various Caribbean countries.

65. The legality of the safe-haven policy was ultimately sustained by the Eleventh Circuit in Cuban-American Bar Ass'n v. Christopher, 43 F.3d 1413 (11th Cir. 1995).

66. See generally Harold Hongiu Koh, America's Offshore Refugee Camps, 29 RichMOND L. Rev. 139, 164-73 (Allen Chair 1994)(arguing that the policy of temporary safe haven on Guantanamo crossed the line into illegal arbitrary detention). 
The larger point is that on such matters, decisions of the U.S. Supreme Court are neither final nor infallible. Such domestic decisions no longer represent final stops, only way stations, in a transnational legal process of "complex enforcement," triggered here by transnational public-law litigation.67 Even resisting nations cannot insulate themselves forever from complying with international law if they regularly participate, as all nations must, in transnational legal interactions. Thus, in the same way that the United States finally abided by the ABM Treaty, the Soviet Union finally conceded that its invasion of Afghanistan was illegal. Through a complex process of rational self-interest and norm internalization-at times spurred by transnational litigation-international legal norms seep into, are internalized, and become entrenched in domestic legal and political processes. In this way, the "normativity of transnational legal process" helps drive how national governments conduct their international relations.

\section{B. Explaining Why Nations Obey}

In recent years, international legal scholars have begun to offer two different accounts of why nations obey international law: one based on interest, the other based on identity. While both theories provide useful insights, neither fully accounts for the importance of interaction within the transnational legal process and domestic internalization of international norms as determinants of why nations obey.

\section{Interest}

The "interest" story is familiar and straightforward. Nation-states obey international law when it serves their short or long-term selfinterest to do so. As contemporary international relations theorists have long recognized, nations are not exclusively preoccupied with maximizing their power vis-à-vis one another in zero-sum games. Rather, they employ cooperative strategies to pursue a more complex and multi-faceted long-run national interest, in which compliance with negotiated norms serves as a winning strategy in a reiterated

67. European human rights litigants have long understood, for example, that adverse national court decisions may be "appealed" to and even "reversed" by the European Court of Human Rights. See, e.g., the European Court's decision in the Sunday Times case, 30 EUr. CT. H. R. [ser.A], Judgment of April 26, 1979, ser. A., no. 30. In that case the British Attorney General sought and won an injunction restraining a British newspaper from publishing a story about thalidomide children. At various stages, eight (of eleven) English judges ruled against the newspaper, but in the end both the European Commission and the European Court ruled in favor of the Times, and required the British government to pay more than 22,000 pounds. For a description of the Sunday Times litigation, see MARK JANIS, AN INTRODUCTION TO INTERNATIONAL LAW 263-64 (2d ed. 1993). 
"prisoner's dilemma" game. Game theory predicts that states, as rational, self-interested actors, will pursue a variety of strategies to achieve both short- and long-term gains, depending on the relative costs and benefits of competition, cooperation, or "defection" from a cooperative scheme. Thus, even when competition or defection provides a short-term advantage, patterns of cooperation may nevertheless emerge from anarchy because "the logic of collective action" convinces self-interested states that cooperation better serves their longer-term interests. 68

Under this account, governmental and private participants in a given issue area will develop a set of governing arrangements-called "regimes"-along with a set of ideologies and expectations, that both restrain the participants and provide means for achieving their common aims. Within these regimes, there is conceptual space for international law: law plays a critical role both in stabilizing the expectations and in reinforcing the restraints that regimes seek to foster. Among rational states, legal rules promote compliance with regime norms by reducing transaction costs, providing channels for dispute-settlement, triggering retaliatory actions, signaling states when negative responses by other states may ensue, and requiring states to furnish information that will highlight defections on their own part.

Recently, a number of international legal scholars, most prominently Kenneth Abbott, have usefully espoused this "rationalistic" view of international law in trade and arms control law.69 At this basic level, international lawyers and international relations theorists now agree that law forms a crucial part of the background against which the complex web of interactions among self-interested nations transpires. 70 Not surprisingly, Abbott's chosen issue areas are ones

68. See, e.g., Robert Axelrod, The Evolution of Cooperation (1984); Robert O. Keohane, After Hegemony: Cooperation and Discord in the World Political Economy (1984); Mancur Olson, The Logic of Collective Action (1971); Robert O. Keohane, International Institutions: Two Approaches, 32 INT'L STUD. Q. 379 (1988); INTERNATIONAL Regrmes (Stephen D. Krasner ed. 1983).

69. See, e.g., Kenneth W. Abbott, Modern International Relations Theory: A Prospectus for International Lawyers, 14 YaLE J. INT'z L. 335 (1989); Kenneth W. Abbott, The Trading Nation's Dilemma: The Functions of the Law of International Trade, 26 HARV. INT'L L.J. 501 (1985); Kenneth W. Abbott, 'Trust But Verify': The Production of Information in Arms Control Treaties and Other International Agreements, 26 CORNELL INT'L L.J. 1 (1993).

70. Yet whether by training or habit, international relations theorists still rarely speak of "law," even while subjects on which they train their sights-compliance, commitments, rules, norms, decisionmaking processes, institutions, and regimes-are increasingly the traditional grist for international law inquiry. "Regime theorists find it hard to say the 'L-word' but 'principles, norms, rules, and decision-making procedures' are what international law is all about ...." Chayes \& Chayes, On Compliance, supra note 5, at 195 n.64. 
where nation-states remain the primary players and traditional realist assumptions still largely prevail. But rationalistic, state-centered theories work far less well, for example, in such areas as human rights, debt restructuring, or international commercial transactions, where nonstate actors abound, pursue multiple goals in complex nonzero-sum games, and interact repeatedly within formal institutional settings nested within broader informal regimes.

Abbott concedes that nonstate actors are critical players in the transnational legal process but deliberately chooses not to focus on them. Nor, because he operates at Kenneth Waltz's "third image"71_ the systemic level-does he have much of a domestic politics story to tell. In Abbott's view, international law regulates behavior by changing national incentives, but does not fundamentally affect state interests. The process he studies is the dynamic interaction among exogenously constituted actors. Abbott sees norms as reducing transactions costs, and explains the evolution of norms, much like Robert Axelrod, 72 as ultimately driven by considerations of long-run self-interest, not through a process of national identity-formation.

\section{Identity}

A second explanation for compliance rests not on interest, but identity. In a string of writings drawing upon emerging "liberal international relations theory,"73 Anne-Marie Slaughter has argued that the determinative factor for whether nations interact in a "zone of law" or a "zone of politics" is whether or not the state can be characterized as "liberal" in identity. 74 In place of Abbott's model of the rational state actor, Slaughter offers the liberal state, defined as a state like the United States, with "some form of representative government secured by the separation of powers, constitutional guarantees of civil and political rights, juridical equality, and a functioning judicial system dedicated to the rule of law."75 Flipping the now-familiar political science maxim that "democracies don't fight one another,"76 Slaughter

71. KENNETh WALtz; MAN, THE STate, AND War (1959).

72. Robert Axelrod, The Evolution of Cooperation (1984).

73. See, e.g., Andrew Moravcsik, Liberalism and International Relations Theory (Center for International Affairs, Harvard University, Working Paper No. 92-6, 1992).

74. See, e.g., Anne-Marie Slaughter Burley, International Law and International Relations Theory: A Dual Agenda, 87 AM. J. INT'L L. 205 (1993).

75. Anne-Marie Slaughter, International Law in a World of Liberal States, 6 EuroPEAN J. INT'L L. 503, 509 (1995). "Non-liberal" states, by contrast, are those that have "neither a representative government nor a market economy." Id. at 529 n.57.

76. Bruce Russett, Grasping the Democratic Peace: Principles for a Post-Cold WAR WorLD 11-23 (1993); Michael Doyle, Kant, Liberal Legacies, and Foreign Affairs, 12 PHII. \& PuB. Afr. 205, 207-08 (1983). 
posits, in effect, that liberal democracies are more likely to do law with one another. Under this view, legal relations among liberal states do and should differ from relations between liberal and illiberal states: the former transpire in a "zone of law," the latter in a "zone of politics beyond law."77

Unlike the rationalistic account, identity theory at least focuses upon both nonstate actors and domestic politics. In its current version, Slaughter's account assumes:

that the primary actors in the international system are individuals and groups acting in domestic and transnational civil society. Thus where Realists look for concentrations of state power, Liberals focus on the ways in which interdependence encourages and allows individuals and groups to exert different pressures on national governments. 78

Nor does liberal theory exclude considerations of transnational legal process. 79

But what this essentialist analysis misses is that a state's identity is neither exogenously nor permanently given. Like national interests, national identities are not givens, but rather, socially constructed products of learning, knowledge, cultural practices, and ideology.80 Nations like Argentina, Chile, Czechoslovakia, and Peru are neither permanently liberal nor illiberal, but make transitions back and forth from dictatorship to democracy, prodded by norms and regimes of international law. A central question facing Haiti, for example, is whether adherence to the rule of international law will help or inhibit its efforts to rebuild its civil society. Thus, identity analysis leaves unanswered a critical question: to what extent does law itself help constitute the identity of a state as one that obeys international law, and hence, as "liberal" or not?

Slaughter's claim that compliance with transnational law marks law among liberal states has a troubling flipside: the notion that nonliberal states somehow participate in transnational process within a

77. See, e.g., Slaughter Burley, Law Among Liberal States: Liberal Internationalism and the Act of State Doctrine, 92 Colum. L. REv. 1907, 1920 (1992)(calling "Transnational Relations Among Liberal and Nonliberal States" "The "Zone of Politics' Beyond Law").

78. Slaughter, supra note 75 , at 508.

79. To the contrary, according to Slaughter, "Liberals assume that the 'State' interacts with these [nonstate] actors in a complex process of both representation and regulation," which yields state preferences. Slaughter, supra note 75, at 508.

80. See Keohane, supra note 68 , at 389-92 (referring to the "cognitivist" or "reflective" models of institutional behavior found in the work of Hayward Alker, Richard Ashley, Friedrich Kratochwil, John Ruggie, and Alex Wendt); Peter Katzenstein, Norms and National Security: The Japanese Police and Military as Agents of Non-Violence, unpublished manuscript presented at Yale Law and International Politics Seminar, April 4, 1994, at 21 ("Norms condition interests, and interests affect norms.") 
zone of politics, not law.81 Strictly understood, this claim denies the universalism of international law and implicitly condones the confinement of nonliberal states to a realist world of power politics. To the extent that identity theory suggests that nations who do not share political cultures are not obliged to deal with one another within the terms of universal law, the claim becomes uncomfortably reminiscent of the "cultural relativism" debate in international human rights law. And if the suggestion is that somehow only liberal states do law with one another, the claim is empirically falsifiable. In such areas as international commercial law-the execution of transborder letters of credit, for example-states regularly abide by international rules without regard to whether or not they are representative democracies or have market economies. 82

\section{Interaction and Internalization}

Neither interest nor identity theory fully account for the normativity of transnational legal process. Participation in the transnational legal process helps constitute the identity of a state as one that obeys the law, but what is critical is the interaction, not the label that purports to identify a state as liberal or not.83 In part, actors obey international law as a result of repeated interaction with other governmental and nongovernmental actors in the international system. A state's violation of international law creates inevitable frictions and contradictions that hinder its ongoing participation within the transnational legal process. As the Alvarez-Machain incident showed, when the U.S. engaged in governmental kidnapping of Mexican citizens, for example, that activity impaired its ability to negotiate the North American Free Trade Agreement with the Mexican government. When a developing nation defaults on a sovereign debt, that activity impairs its ability to secure new lending. When the United States denies the jurisdiction of the International Court of Justice in a suit in which it is a defendant, that decision impairs its ability to in-

81. See, e.g., Slaughter, supra note 77, at 1920 (calling "Transnational Relations Among Liberal and Nonliberal States" "The 'Zone of Politics' Beyond Law). Slaughter sometimes seems to suggest that domestic courts have an expanded role to play in sustaining international order-but only among certain statesand that legal order can be established transnationally, but based only on the common values and institutions shared by liberal states. Id. See also Slaughter, supra note 75, at 504 (thought experiment).

82. F. Dely, International Business Law and Lex Mercatoria (1992).

83. Slaughter's most recent work recognizes this by deemphasizing the liberal/illiberal label and emphasizing two transnational legal process elements: the density of transnational transaction and transgovernmental communication among transnational actors. Slaughter, supra note 75, at 522-28. As I argue in the text, these aspects of transnational legal process, and not the "liberal" label, explain the phenomenon of compliance with transnational law. 
voke the Court's jurisdiction as a plaintiff. 84 Thus, a nation's leaders may shift over time from a policy of violation of international law to one of compliance to avoid such frictions in its continuing interactions.

As transnational actors interact, they create patterns of behavior and generate norms of external conduct which they in turn internalize. Law-abiding states internalize international law by incorporating it into their domestic legal and political structures, through executive action, legislation, and judicial decisions which take account of and incorporate international norms. ${ }^{85}$ Nations also react to other states' reputations as law-abiding or not. Legal ideologies prevail among domestic decision-makers such that they are affected by perceptions that their actions are unlawful, or that domestic opponents or other nations in the global regime will so categorize them. Moreover, domestic decision-making becomes "enmeshed" with international legal norms, as institutional arrangements for the making and maintenance of an international commmitment become entrenched in domestic legal and political processes. 86 It is through this repeated process of interaction and internalization that international law acquires its "stickiness," that nation-states acquire their identity, and that nations define promoting the rule of international law as part of their national selfinterest.

The example of the $55 \mathrm{mph}$ speed limit used above helps make the point. After the oil crisis of 1974, why did American drivers start driving slower on the highways? Perhaps in part because individual drivers recalculated their self-interest, and determined that it was rational to drive slower because of safety reasons or to save gas. It may in part have been because many citizens view themselves as lawabiding, and complied with the law because of their sense of self-identity. But other factors were also undoubtedly at work. Those who drove repeatedly-e.g. interacted within the process-encountered highway patrols and other enforcement mechanisms. Complying vehicles blocked lanes and made it harder to speed. Federal standards crept down and became incorporated into state laws. Authorities exhorted drivers, using threats, tickets and appeals to patriotism, to in-

84. See, e.g., Nicaragua's suit against the United States, Military and Paramilitary Activities (Nicar. v. U.S.), 1986 I.C.J. Rep. 14 (June 27).

85. One prime example is the refugee area and the international law norm of nonrefoulement. Not only is that norm embodied in the 1951 Refugee Convention, it has been internalized in the 1981 U.S.-Haiti Agreement and § 243(h) of the Immigration and Nationality Act. The Haitian Centers Council litigation can thus be understood as an unsuccessful attempt by private litigants to convince the Supreme Court to internalize the norm of extraterritorial nonrefoulement as United States domestic law.

86. See Robert O. Keohane, Compliance with International Commitments: Politics within a Framework of Law, in International Law and International Relations Theory: Building Bridges, American Society of International Law, Proceedings of the 86th Annual Meeting 167 (1992)(describing concept of "enmeshment"). 
ternalize the new norm. Drivers in many jurisdictions came to view noncompliance as costly while viewing the new rule itself as legitimate and generally fair. Was the new law enforced? Most would agree that it was underenforced, that it was enforced through a complex enforcement process, but few would deny that the law mattered. As an independent variable, the law affected conduct. Interaction and internalization (which together comprise the normativity of the process) provided a critical link between the explanatory variable of interest, on the one hand, and identity on the other. In the same way, as nations participate in transnational legal process, through a complex combination of rational self-interest, transnational interaction, norminternalization, and identity-formation, international law becomes a factor driving their international relations.

To summarize, the critical idea is the normativity of transnational legal process. To survive in an interdependent world, even the most isolated states-North Korea, Libya, Iraq, Cuba-must eventually interact with other nations. Even rogue states cannot insulate themselves forever from complying with international law if they wish to participate in a transnational economic or political process. Once nations begin to interact, a complex process occurs, whereby international legal norms seep into, are internalized, and become embedded in domestic legal and political processes.

In some cases, of course, instead of returning to compliance, the noncomplying state seeks actively to promote its departure from international norms as the new governing international rule.87 In the same way as a river that has overflowed its banks may either recede or carve a new path, the noncomplying government may try to argue internationally - as the United States did in the ABM Treaty Debate and before its own Supreme Court in the Alvarez-Machain and Haitian cases-that the contested norm it is violating should be reinterpreted so as to avoid any claim of violation. Yet such arguments, when made, do not settle the question of international legality. Instead, they stimulate another round of transnational legal interaction, in which the integrity of the revised norm can be challenged and tested by other nations and nongovernmental actors. The transnational legal process of institutional dialogue begins again, starting with a debate over whether to amend or reinterpret the norm in light of the new circumstances. 88

87. See, e.g., Ted L. Stein, The Approach of the Different Drummer: The Principle of the Persistent Objector in International Law, 26 HARV. INT'L L.J. (1985).

88. An analogous process has occurred in the United States with regard to the death penalty, whereby individual states have progressively taken narrower views of what constitutes cruel and unusual punishment, thereby prompting Supreme Court reconsideration of the Eighth Amendment rule. See, e.g., Stanford v. Kentucky, 492 U.S. 361 (1989). 


\section{CONCLUSION}

If one accepts a theory of transnational legal process, what conclusions follow? Let me quickly suggest four.

First, like postwar international relations theories, a theory of transnational legal process has both predictive capacity 89 and explanatory power regarding questions of causation. It predicts that nations will come into compliance with international norms if transnational legal processes are aggressively triggered by other transnational actors in a way that forces interaction in forums capable of generating norms, followed by norm-internalization. This process of interaction and internalization in turn leads a national government to engage in new modes of interest-recognition and identity-formation in a way that eventually leads the nation-state back into compliance.90

Second, this is a theory that well serves our comparative advantage as lawyers. Unlike political scientists, lawyers specialize in the close reading of texts, examining the social impact of procedural rules, understanding the power of norms in civil society, and designing public policy against a backdrop of law. A lens of transnational legal process calls upon lawyers to exercise all of their interdisciplinary tools, without asking them to forsake their traditional lawyerly skills. 91

Third, the theory suggests the value and the imperative of clinical work in international law. Transnational legal process forces states to become more law-abiding by incorporating international law into their

89. "This reasoning," I argued shortly before the Clinton Administration's 1994 policy change regarding Haitian refugees, "predicts that in time, the United States will comply with the norm of 'extraterritorial nonrefoulement.' " See Koh, Haiti Paradigm, supra note 4 , at 2408 .

90. By this reasoning, North Korea and Libya will eventually permit international inspections of their nuclear facilities, Guatemala will acknowledge its extrajudicial killings, Japan will acknowledge the illegality of its unilateral trade actions and its wartime treatment of Korean comfort women, and the United States will eventually comport with norms against arbitrary detention with respect to its offshore refugee detention policy. See Koh, America's Offshore Refugee Camps, supra note 66. For an effort to trace how American domestic political processes took account of and incorporated the international norm against refoulement with respect to Haitian refugees, substituting in its place a rule of temporary safe haven, see Koh, Refugees, the Courts, and the New World Order, supra note 4, at 999.

91. Political scientists may say, for example, that they saw no effect of law upon the resolution of the ABM treaty debate, the extraterritorial kidnapping affair, or the Haitian refugee crisis discussed in text. But to me, these are simply matters of not looking closely enough, of failing to trace the process of compliance. A scientist passing a magnet over a chemical solution may change all of the ions from positive to negative, without affecting any change visible to the uninformed observer. In the same way, lawyers tracing transnational legal process can trace in ways that political scientists often miss the minute modes by which law affects the incentives of political actors, thereby changing the receptivity of those actors to compliance with legal rules. 
domestic legal and political structures. When such a state violates international law, that violation creates frictions and contradictions that disrupt its ongoing participation in the transnational legal process. 92 Transnational public law litigation brought by nongovernmental organizations is designed precisely to provoke judicial action that will create such frictions, thereby helping shape the normative direction of governmental policies.

If this is so, nongovernmental organizations are not just observers of, but important players in, transnational legal process. Their actions influence the process and their inaction ratifies its outcomes. It is sometimes said that someone who, by acquiring medical training, comes to understand the human body acquires as well a moral duty not just to observe disease, but to try to cure it. In the same way, I would argue, a lawyer who acquires knowledge of the body politic acquires a duty not simply to observe transnational legal process, but to try to influence it. To use $H$. Ross Perot's blunt words, if a lawyer really cares about international human rights, "you can't just talk about it, you've got to do it."

Fourth and finally, transnational legal process fills the hole in the doughnut of international legal scholarship. What I have suggested is that what mainstream scholars in international law have been doing these last forty years has not been simply thick description, but examination of the complexity and normativity of transnational legal process. Like the new public law scholars in the domestic realm, the transnational legal process scholars of my generation are focused on the normativity of process, sensitive to practice, and alive to interdisciplinary theory. Even a cursory examination of most journals of international law over the last few decades reveals that most international legal scholars have been pursuing not law and economics, postmodernism, or critical theories, but applied studies in transnational legal process. 93 In Moliere's famous words, "Good heavens, for more than forty years I've been speaking prose without knowing it."94 In the same way, for more than forty years, international legal scholars have been studying transnational legal process without knowing it. In the end, fathoming international law's role in the postCold War era means participating, influencing, and ultimately enforcing transnational legal process: the key to understanding why nations obey.

92. See, e.g., KoH, The National Security Constitution, supra note 48 , at 155 ("Because the United States is a party to a network of closely interconnected treaties, unilateral administration decisions to break or bend one treaty have forced it into vicious cycles of treaty violation.").

93. See, e.g., ChaYes, supra note 32; Henkin, supra note 5; REISMan \& WinLARD, supra note 13.

94. Moliere, The Bourgeois Gentleman (1670). 